\title{
Anti-amyloid-beta to tau-based immunization: developments in immunotherapy for Alzheimer's disease
}

This article was published in the following Dove Press journal:

ImmunoTargets and Therapy

10 August 2013

Number of times this article has been viewed

\section{Doris Lambracht- \\ Washington \\ Roger N Rosenberg}

Department of Neurology and Neurotherapeutics, Alzheimer's

Disease Center, University of Texas Southwestern Medical Center, Dallas, TX, USA
Correspondence: Doris LambrachtWashington

Department of Neurology and Neurotherapeutics, Alzheimer's Disease Center, University of Texas Southwestern Medical Center, 5323 Harry Hines Boulevard, Dallas, TX 75390-9036, USA

Email doris.lambracht-washington@ utsouthwestern.edu
Abstract: Immunotherapy might provide an effective treatment for Alzheimer's disease (AD). A unique feature of $\mathrm{AD}$ immunotherapies is that an immune response against a self-antigen needs to be elicited without causing adverse autoimmune reactions. Current research is focused on two possible targets in this regard. One is the inhibition of accumulation and deposition of amyloid beta 1-42 (A 342 ), which is one of the major peptides found in senile plaques, and the second target is hyperphosphorylated tau, which forms neurofibrillary tangles inside the nerve cell and shows association with the progression of dementia. Mouse models have shown that immunotherapy targeting $\mathrm{A} \beta 42$ as well as tau with the respective anti-A $\beta$ or anti-tau antibodies can provide significant improvements in these mice. While anti-A $\beta$ immunotherapy (active and passive immunizations) is already in several stages of clinical trials, tau-based immunizations have been analyzed only in mouse models. Recently, as a significant correlation of progression of dementia and levels of phosphorylated tau have been found, high interest has again focused on further development of tau-based therapies. While $A \beta$ immunotherapy might delay the onset of $\mathrm{AD}$, immunotherapy targeting tau might provide benefits in later stages of this disease. Last but not least, targeting $A \beta$ and tau simultaneously with immunotherapy might provide additional therapeutic effects, as these two pathologies are likely synergistic; this is an approach that has not been tested yet. In this review, we will summarize animal models used to test possible therapies for $\mathrm{AD}$, some of the facts about $\mathrm{A} \beta 42$ and tau biology, and present an overview on halted, ongoing, and upcoming clinical trials together with ongoing preclinical studies targeting tau or $\mathrm{A} \beta 42$.

Keywords: immunotherapy, prevention trials, active and passive vaccination, tau protein, amyloid precursor protein, $\mathrm{A} \beta 42$, neurofibrillary tangles

\section{Introduction}

Alzheimer's disease (AD) is the sixth-leading cause of death in the US, and until now there has been no effective treatment available. ${ }^{1}$ Current treatment options are only symptomatic and do not affect disease progression. Immunotherapy in which antibodies directed against the two pathophysiological hallmarks of $\mathrm{AD}$ - amyloid plaques with amyloid beta $1-42(\mathrm{~A} \beta 42)$ as their major component and neurofibrillary tangles (NFTs) that are formed by hyperphosphorylated tau - are possible targets for an immunotherapeutic intervention. Both pathophysiological features are formed from aberrant self-proteins: a major component of the amyloid plaques is $A \beta 42$, which is a small proteolytic fragment from the amyloid precursor protein (APP) with the tendency to aggregate into insoluble fibrils, and the NFTs are derived from hyperphosphorylation of the protein tau, which makes this protein insoluble and leads to aggregate formation 
and malfunction. ${ }^{2}$ Other changes in $\mathrm{AD}$ brain include inflammation and oxidative stress. ${ }^{3}$ All of these features lead to severe dysfunction, neurodegeneration, and neuron loss, and end-stage brain from AD patients shows a substantial loss in weight compared to brains of age- and sex-matched nondemented individuals. The most neurotoxic form of $A \beta$ is not the solid plaques but the oligomeric forms of $A \beta 42$. In rodents, a dodecameric form of $A \beta 42$, which was isolated from brains of APP transgenic mice, leads directly to impairment of synaptic plasticity and memory. ${ }^{4}$ In humans, the same feature was described for an $\mathrm{A} \beta 42$ dimer, which had been isolated from human $\mathrm{AD}$ brains. ${ }^{5} \mathrm{~A}$ recent study showed that all of these $A \beta 42$ oligomers, dimers, trimers, and dodecamers (A $\beta 56)$ can be isolated from human brain and cerebrospinal fluid (CSF) and A $\beta 56$ levels correlated positively with levels on soluble tau protein in brain from $\mathrm{AD}$ patients. ${ }^{6}$ The description of $A \beta 42$ aggregation as being outside the nerve cells and tau aggregates being found only inside neurons may not be as strict as proposed. There is evidence that $A \beta$ accumulation occurs first inside the nerve cell and accumulates outside the neurons as disease progresses, and for tau it has also been shown in in vitro and in vivo models that extracellular tau aggregates lead to uptake of these aggregates by the nerve cells in which they induce intracellular tau aggregation, and that the injection of insoluble tau, and to a lesser extent the injection of soluble tau, into mouse brains leads to spreading of tau pathology. ${ }^{7-11}$

\section{Animal models}

In familial $\mathrm{AD}$ (FAD), which accounts for less than $5 \%$ of all $\mathrm{AD}$ cases, mutations were discovered within the $A P P$ gene or in genes encoding enzymes involved in the proteolytic degradation of APP, presenilin (PS)-1 and -2, which increase the amyloidogenic processing of APP, and are thus leading to increased A $\beta 42$ levels. ${ }^{12}$ Based on these mutations, transgenic mouse models were developed that recapitulate some of the features seen in humans. Even though not a perfect replica for the human disease, the mouse models were helpful in discovering mechanisms by which $\mathrm{A} \beta$ oligomers and tau oligomers were directly leading to dysfunction and toxicity. ${ }^{13}$ These mouse models also showed that immunotherapy can modify the development of disease. ${ }^{14}$ In experiments for A $\beta 42$ immunotherapy, most often used is a double transgenic mouse, which carries a chimeric mouse/human amyloid precursor protein gene (Mo/HuAPP695 Swe) and the gene for mutant human PS1 (PS1-dE9), which are expressed under regulation from different strong promoter sequences, such as the prion protein, platelet-derived growth factor, or the Thy- 1 promoter. These transgenic mice develop A $\beta 42$ deposits and senile plaques in the brain by $6-7$ months of age. ${ }^{15}$ While there have been no tau mutations observed in $\mathrm{AD}$, a mutated human tau gene $(P 301 S$ or $P 301 L)$ has been associated with forms of frontotemporal dementia with tangle pathology. Mice transgenic for this particular human gene provide tools to study tau pathology and tangle-related neurodegeneration, as well as the evaluation of potential therapies. These mice show the age-dependent development of NFTs, and develop progressive motor dysfunctions correlating with the loss of motor neurons in later stages. ${ }^{16}$ A triple-transgenic mouse model, which combines $A \beta$ and Tau pathology carrying the mutated human $A P P$ and mutated human microtubule-associated protein tau (MAPT) gene, and even a quintuple-transgenic mouse model $(5 \times$ FAD $)$ that combines three APP and two PS1 FAD mutations has been generated in an effort to make this model more complete. ${ }^{17-20}$ An important new animal model was recently described in the rat. Rats transgenic for human $A P P \mathrm{~s}$ and the mutant human PS1 (PS1-dE9) genes developed many of the characteristic features of AD: amyloid plaques, tau tangles, and memory deficits, as well as loss of neurons and neurodegeneration. ${ }^{21}$ Different from the mouse models, rats developed the NFTs "naturally," which is in strong support of the order of the pathophysiological findings: $A \beta$ accumulation first, followed by tangle formation. The explanation for this important difference from the mouse models is that the tau proteome is much closer to the human tau proteome than mouse tau. While the mouse expresses only three different tau isoforms in the brain, which is due to the lack of exon 10 splicing, the rat expresses the same six tau protein isoforms that are found in human brain..$^{22,23}$

\section{Amyloid precursor protein}

APP is a type 1 transmembrane protein with a large extracellular domain and a short intracellular segment that is expressed in many tissues, with the highest expression level in the brain. A role for APP in neural tissue is synaptic formation and repair; APP expression is upregulated during differentiation and after neural injury. ${ }^{24,25}$ Depending on whether APP is processed via the $\alpha$-secretase or the $\beta$-secretase pathway, the products are nonamyloidogenic or amyloidogenic, respectively. ${ }^{26}$ The aforementioned mutations within the $A P P$ gene, which cause FAD, have been found to dramatically increase production of A $\beta 42 .{ }^{12}$ Recently, a new mutation within the APP gene was described that showed protection against AD. The APP substitution $\mathrm{A} 673 \mathrm{~T}$ is adjacent to the $\beta$-secretase cleavage site, leading to a $40 \%$ reduction in overall $A \beta 42$ levels. ${ }^{27}$ These 
findings strongly support the amyloid-cascade hypothesis, which was postulated more than 20 years ago that posits that $\mathrm{A} \beta$ accumulation, while it may not be the initial event, plays a central role in the multifactorial pathogenesis of $\mathrm{AD}{ }^{28-31}$

\section{Clinical human studies: anti-A $\beta$ immunization}

Following the observations that $\mathrm{A} \beta 42$ accumulation in brain is strongly associated with the development of $\mathrm{AD}$, immunizations against $\mathrm{A} \beta$ were tested in $\mathrm{AD}$ mouse models. Results showed that this treatment can indeed lead to reduction of total amyloid levels in brain, as well as removal of the senile plaques. Most importantly, a significant effect from the immunotherapy had been shown on mouse memory and performance in behavioral tests. ${ }^{14,32-34}$

The first clinical trial, AN1792, in which AD patients received $A \beta 42$ peptide injections to induce an antibody immune response, was stopped when $6 \%$ of the treated patients developed meningoencephalitis. ${ }^{35-37}$ But besides the negative side effect, it appeared that $A \beta 42$ immunotherapy had worked in regard to reduction of overall $A \beta 42$ and plaque counts in the brains of immunized patients, even though it did not stop the progression of dementia. ${ }^{38}$ As immunotherapy has great potential as a disease-modifying intervention in contrast to the currently available symptom-only treatment options, major efforts are in progress to make this therapy for AD safe and effective, and number of active and passive immunotherapies targeting $\mathrm{A} \beta$ peptides are currently in clinical trials.

Based on the observed negative side effect from AN1792 with autoimmune T-cell responses, all of the active immunization trials are now concentrated on the B-cell epitope (A $\beta 1-6$ or $A \beta 1-15)$ to produce antibodies while avoiding a possible inflammatory T-cell response. Three of these epitope peptide vaccines for active immunizations - CAD106, (Novartis, Basel, Switzerland), ACC-001 (Elan Corporation, Dublin, Ireland), and Affitope (Affiris AG, Vienna, Austria) - are currently in phase II clinical trials. In the CAD106 vaccine, $A \beta 1-6$ is coupled to a heterologous carrier protein to optimize an immune response, and in the Affitope vaccine, a peptide is used that mimics the $\mathrm{A} \beta \mathrm{B}$-cell epitope but has no sequence similarities. ${ }^{39-41}$ Positive antibody titers and no adverse autoimmune inflammation has been found in clinical trials using these new epitope vaccines. New results were also recently reported from mouse studies using very similar constructed epitope peptide vaccines for potential use in $\mathrm{AD}$ patients. ${ }^{42,43}$

The most promising approach for AD immunotherapy is currently passive immunization with humanized
anti-A $\beta$ antibodies. In this approach, preformed anti-A $\beta 42$ antibodies are injected intravenously (IV) with the goal that these antibodies will help to reduce amyloid burden in the brain of AD patients by several possible mechanisms, such as facilitation of phagocytosis of amyloid by microglia, inhibition of amyloid aggregation, or binding of antibodies to amyloid in blood causing a concentration gradient with net efflux of $A \beta 42$ from brain. Observed complications from the injection with some of the monoclonal antibodies (mAbs) is that they show a tendency to cause vasogenic edema and brain microhemorrhage, which have been reported also in mouse models. ${ }^{44-46}$ Three of the monoclonal antibody therapies solanezumab from Eli Lilly and Company (Indianapolis, IN, USA), crenezumab from Genentech, (San Francisco, CA, USA), and gantenerumab from Hoffmann-La Roche (Basel, Switzerland) - are in phase II and III clinical trials and ongoing. ${ }^{47-52} \mathrm{~A}$ fourth antibody trial, investigating bapineuzumab from Pfizer, (New York, NY, USA), which was completed in 2012, was discontinued when the results obtained did not meet the predicted results. ${ }^{53}$

Solanezumab and crenezumab are humanized mouse mAbs detecting a mid-region $A \beta$ epitope, $A \beta 13-28$, and A $\beta 12-23$. Solanezumab has a good safety profile, and showed in patients with mild AD the slowing of cognitive decline compared with placebo by one-third. ${ }^{49}$ An increase of $A \beta 42$ levels in CSF might indicate that this antibody, which binds preferentially soluble forms of $A \beta$, has the ability to mobilize $A \beta$ from brain amyloid depositions. ${ }^{50}$ The mAb crenezumab was further modified to carry a certain human immunoglobulin ( $\mathrm{Ig}$ )-G isoform, $\mathrm{IgG}_{4}$, which is a Th2 antibody isotype carrying noninflammatory features such as reduced Fc-receptor binding on other immune cells. Indeed, results from a phase I clinical trial showed that patients treated with crenezumab showed less brain microhemorrhage and vasogenic edema compared to published observations from other antibody immunotherapy studies. ${ }^{47,51}$ Gantenerumab is a fully human monoclonal $\mathrm{IgG}_{1}$ antibody detecting two separate epitopes in $A \beta 42$ (A $\beta 3-11$ and $A \beta 19-28)$, and it has been reported that this antibody does not bind soluble $A \beta$ but only the fibrillar forms of $\mathrm{A} \beta$. In vitro studies showed that gantenerumab can induce phagocytosis of $A \beta$ fibrils by brain microglia. ${ }^{48}$ In patients, a decrease of brain amyloid was found in an antibody dosedependent manner by up to $30 \%$, as shown by positron emission tomography (PET) scans with the fibrillar A $\beta$-specific Pittsburgh B compound. ${ }^{52}$

Another drug to treat AD with anti-A $\beta$ antibodies, Gammagard from Baxter International (Deerfield, IL, 
USA), which is in phase III clinical trials and had shown favorable results to some extent, has failed to meet primary end points such as the slowing of cognitive and functional decline in treated $\mathrm{AD}$ patients, and is thus under debate whether trials of it will continue. ${ }^{53}$ In this study, patients with mild-to-moderate AD received injections of concentrated Ig (IVIg) from healthy persons to utilize naturally occurring autoantibodies that specifically recognize and block the toxic effects of $A \beta$ (nAbs-A $\beta$ ). The level of anti-A $\beta$ antibodies in the serum from $A D$ patients increased in proportion to the IVIg dose administered, and CSF A $\beta$ decreased significantly at 6 months of continued treatment, then returned to baseline when treatment was stopped, and decreased again with continuous IVIg treatment, indicating that the naturally occurring anti-A $\beta$ antibodies mobilized $A \beta$ from brain. Mini-mental state scores increased an average of 2.5 points with 6 months of treatment and remained stable with treatment was continued. ${ }^{54-57}$ In a phase II dose-finding clinical study performed in the US and Germany in which AD patients also received IVIg injections (Octagam ${ }^{\circledR}$, Octapharma, Toronto, ON, Canada), the main focus was on the safety profile of this therapy. ${ }^{58}$ In the 6-month treatment period, $14 \%$ of patients showed brain microbleeds and one patient had an ischemic stroke, both of which are known side effects of IVIg therapy. The conclusion from this trial was that IVIg has tolerable safety and that further studies with larger patient cohorts and longer treatment times are needed to draw decisive conclusions.

\section{New AD-prevention trials}

One of the main arguments for the lack of more definitive positive results from clinical trials in $\mathrm{AD}$ is that the treatment was started too late. ${ }^{59-61}$ It has been shown that A $\beta 42$ concentrations in CSF decline 25 years before the onset of clinical symptoms, which indicates $A \beta$ deposition in brain, and 15 years before clinical symptoms are noticeable; these fibrillar $A \beta$ deposits are visible in PET scans with fibrillar A $\beta$-specific Pittsburgh compound B. ${ }^{60}$ Thus, a likely effective prevention and/or intervention have to start much earlier and in patients which do not already show symptoms for AD.

Three major prevention trials are slated to start in 2013: (1) the DIAN (Dominantly Inherited Alzheimer Network) study, (2) the Alzheimer's Prevention Initiative (API) study, and (3) the Anti-Amyloid Treatment of Asymptomatic Alzheimer's Disease (A4) study. These studies will focus on therapy in patient cohorts before the onset of clinical symptoms of AD.
The DIAN study will be undertaken in patients who are highly likely to develop AD at an early age, as these patients are carriers of genetic mutations that cause FAD. Treatment methods will be immunotherapy with two anti-A $\beta$ mAbs, solanezumab and gantenerumab, and as a different treatment option a $\beta$-secretase inhibitor (LY2886721 from Lilly) will be used, which reduces $A \beta$ deposition, as this reagent blocks the $\beta$-secretase enzyme involved in APP turnover on the cell surface. ${ }^{60,62}$ Also the API study will be undertaken in FAD patients: a large group of FAD carriers in Colombia which will develop AD early with end-stage dementia around the age of 50 years, which is decades earlier than the typical sporadic AD case. In the API study, the patients will receive passive immunizations with the mAb crenezumab. ${ }^{51,63}$ The A4 study will focus on the most often found form of AD, which is sporadic AD. Enrollment groups for this trial are older patients who are not genetic carriers, but already show early stages of $A \beta$ deposition in the brain as measured by PET scan. In this study, passive immunotherapy will be done with the $\mathrm{mAb}$ solanezumab, which binds soluble $\mathrm{A} \beta$, and the hope is that this early treatment will clearly show that treatment before the occurrence of clinical symptoms will lead to better benefits by blocking $A \beta$ accumulation and delay the onset of AD. ${ }^{64}$

\section{Other alternatives for active $A \beta$ immunotherapy}

DNA immunizations differ in many ways from peptide immunizations, and in the search for alternative active immunization therapies, many groups, including ourselves, are investigating this vaccination route. ${ }^{65-72}$ In DNA immunizations, the DNA encoding the respective antigen is injected into skin or muscle. The DNA is then transcribed and expressed at the injection site. Local dendritic cells will take up the antigen, migrate to local lymph nodes, and present the protein to circulating lymphocytes, thereby initiating a general immune response. Our reports on the effectiveness of DNA $A \beta 42$ immunization in the AD transgenic mouse model were the first to show that $A \beta 42$ levels in the brain were reduced by $41 \%$ and $A \beta 42$-containing plaques reduced by $50 \% .{ }^{66,67}$ Similar findings were described by others in later studies. ${ }^{71}$

Figure 1 shows the results from two groups of DNA A $\beta 42$ trimer-immunized APP/PS1 double-transgenic mice and the respective control DNA (luciferase [Luc])-immunized mice (our group, unpublished results). These mice had been immunized eleven times with DNA A $\beta 42$ trimer or Luc DNA, respectively, via gene gun starting at 4 months of age. The 


\section{Group A}

\section{Group B}

C

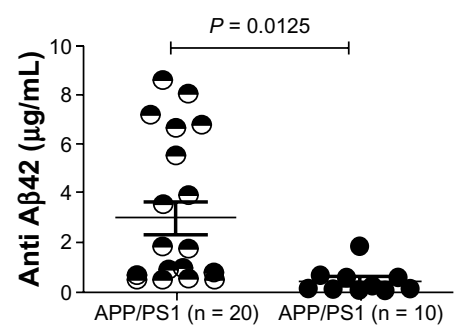

DNA A 1 1-42 trimer/14 days post immunization

DNA A $\beta 1-42$ trimer/4 months post immunization
A

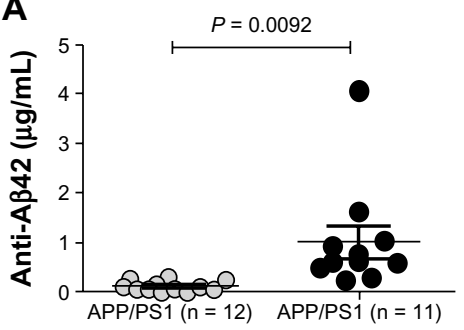

APP/PS1 $(n=12) \quad$ APP/PS1 $(n=11)$
B

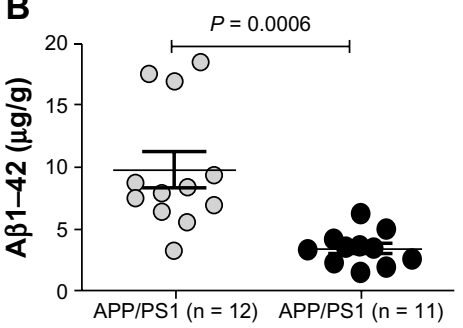

DNA LUC

DNA A $31-42$ trimer

E

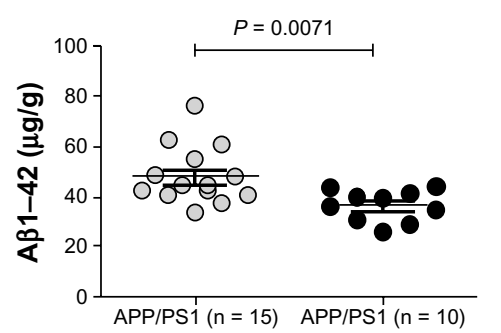

D

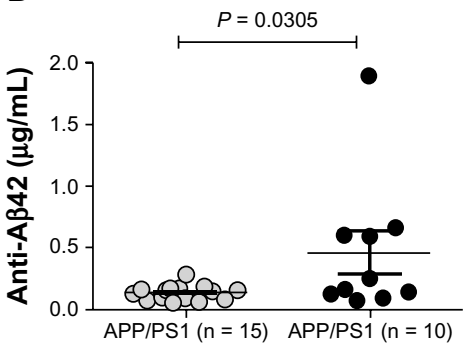

O DNA Luc

DNA A $\beta 1-42$ trimer

Figure I (A-E) Effective amyloid beta $(A \beta)$ immunotherapy in an Alzheimer's disease mouse model with active DNA A 42 trimer immunization. Results from two groups of DNA A 342 trimer-immunized APP/PSI double transgenic mice and the respective control DNA-immunized mice are shown (n on the $x$-axis indicates the number of mice used in this particular experiment). Immunization was started in both groups in 4-month-old mice and was continued for eleven immunizations until the mice were 12 months old. Group A was killed for final analyses (plasma antibody levels, brain A $\beta$ histology, and biochemistry) 14 days following the last immunization, while mice in group B were killed four months after the eleventh immunization. Anti-A $\beta 42 \lg G$ antibody levels were shown in (A) for group $A$, and in (C and $\mathbf{D})$ for group $B$. The comparison of plasma anti-A $\beta 42$ levels of DNA A 342 -immunized mice and control mice that had received DNA luciferase (Luc), immunizations showed in both groups the presence of A $\beta 42$-specific antibodies in the DNA A $\beta 42$-immunized mice $(P=0.0092$ [A] and 0.0305 [D]). In both groups, a significant reduction of $A \beta 42$ levels in brain was found in the DNA A 342 -immunized mice in comparison to the respective control groups. Mice in group A showed an amyloid reduction of $60 \%$ (B), while mice in group $B$ showed a reduction of $A \beta 42$ brain levels of $25 \%$ (E). This difference might be due to the time differences in the two groups between final immunizations and brain level analyses, as well as the marked differences in total A $\beta 42$ levels in brain due to the 4-month age difference between the analyses for mice in groups $A$ and $B$. Symbols used in the diagrams are as follows: in (A, B, D, and E), the grey circles show values from Luc-immunized control mice, and the black circles show values from DNA A 342 -immunized mice. In (C), the antibody levels were compared in the same mouse group (Group B) I4 days after the final immunization (divided black and white circles) and 4 months after the final immunization (black circles). For statistics (unpaired $t$-test with two-tailed $P$-values). $P$-values of $\leq 0.05$ were considered significant.

Abbreviations: APP, amyloid precursor protein; PSI, presenilin I.

mice in group A had been analyzed 14 days following the final immunization, while the mice in group B were analyzed 4 months following the final immunization. The graphs show a comparison of anti-A $\beta 42$ antibody levels (Figure $1 \mathrm{~A}, \mathrm{C}$, and $D)$ and total $A \beta 42$ peptide levels in the brains from these mice (Figure 1B and E). Data shown were obtained by enzyme-linked immunosorbent assay (ELISA) experiments (plates coated with $A \beta 42$ peptide for detection of the anti-A $\beta 42$ antibodies or coated with an anti-A $\beta 42$ antibody for detection of $A \beta 42$ in a sandwich ELISA protocol). In both groups, the $A \beta 42$ levels in brain from the DNA A $\beta 42$ trimerimmunized mice were significantly reduced in comparison to Luc DNA-immunized control animals. In Figure 1B, the A $\beta 42$ levels were reduced $60 \%$ compared to the parallel Luc-immunized control mice $(9.795 \pm 1.455 \mu \mathrm{g}$ A $\beta 42$ peptide per gram of brain tissue in control mice was reduced to
$3.418 \pm 0.418 \mu \mathrm{g}$ A $\beta 42$ peptide in DNA A $\beta 42$-immunized mice), while in Figure $1 \mathrm{E}$ the $\mathrm{A} \beta 42$ levels were reduced by $25 \%(48.16 \pm 2.914 \mu \mathrm{g} A \beta 42$ peptide per gram of brain tissue in control mice was reduced to $36.55 \pm 1.964 \mu \mathrm{g} A \beta 42$ peptide in DNA A $\beta 42$-immunized mice). Both these findings were highly significant, with $P$-values of 0.0006 and 0.0071 , respectively. An explanation for this difference is in the time intervals between the final immunizations and the respective analyses of $A \beta$ brain levels. While the mice in group $A$ were still actively producing new antibodies (A $\beta 42$ antibody levels in plasma and $A \beta 42$ peptide levels in brain were shown 14 days after final immunization), in group $\mathrm{B}, \mathrm{A} \beta 42$ reduction in brain was analyzed 4 months after the final immunization. Consistent with this, total $A \beta 42$ levels in brains were much higher in group B with mean values of $48.2 \mu \mathrm{g} / \mathrm{g}$ wet brain tissue in the control mice compared to $9.7 \mu \mathrm{g} / \mathrm{g}$ wet brain 
tissue in the control mice of group A, in line with the marked increase of $A \beta$ pathology with an age difference of 4 months (group A was 12 months of age, group B 16 months of age). The anti-A $\beta$ antibody plasma levels were markedly reduced after a 4-month period without booster immunizations in direct comparison to the antibody levels 14 days postimmunization (Figure $1 \mathrm{C}, P=0.0125$ ), but even with the reduced antibody levels in plasma, the reduction of $A \beta 42$ brain levels was still significantly different from the Luc DNA-immunized control mice (Figure 1E), and this was shown with the much higher levels of total $A \beta 42$ in brain (compare $10 \mu \mathrm{g} / \mathrm{g}$ in 12-month-old mice [Figure 1B] and $48.2 \mu \mathrm{g} / \mathrm{g}$ wet brain tissue in 16-month-old Luc immunized control mice [Figure 1E]) showing that DNA A $\beta 42$ immunotherapy is effective.

DNA immunization differs quantitatively and qualitatively from peptide immunizations, and we and others have shown that $A \beta 42$ DNA vaccination using a gene-gun approach results in a polarized Th2 immune response. ${ }^{65,68-72}$ In our comparisons of DNA and peptide immunizations, we found that in vitro cell proliferation of potentially inflammatory A $\beta 42$-specific $T$ cells was absent in full-length DNA A $\beta 42$ trimer-immunized mice, making this approach effective and safe for possible immunotherapy in AD patients. ${ }^{73,74}$

\section{Biological role of tau protein}

Tau is a highly soluble cytoplasmic protein that is primarily found in the brain and functions in neurite outgrowth, axonal transport, and microtubule assembly and stability. Neuronal development requires dynamic microtubules with axonal elongation and shortening, while in differentiated neurons the microtubules are relatively stable, and tau participates in these processes by microtubule binding. Alternative splicing and tau phosphorylation allow all these different functions from a single gene. Six isoforms as the result of alternative splicing of the 13 exons encoded by the MAPT gene are found in the human brain, and all of them are likely to have a specific role as they are differently expressed during development. Tau proteins differ by having three (3R) or four (4R) microtubule-binding repeats of 31-32 amino acids each, and possessing one, two, or no amino terminal inserts of 29 amino acids each $(36.8-45.9 \mathrm{kDa})$. Alternative splicing of exon 10 results in the $3 \mathrm{R}$ and $4 \mathrm{R}$ isoforms. Tau phosphorylation on specific sites modulates function and intracellular localization. Hyperphosphorylated tau protein dissociates from the neuronal microtubule cytoskeleton, leading to microtubule destabilization and the formation of paired helical filaments (PHFs), which precipitate and become visible tangles. ${ }^{75}$ Furthermore, nonfunctional tau sequesters normally phosphorylated tau proteins, preventing them from binding to microtubules and leading to more dysfunction. While certain sites are phosphorylated early, such as Ser202 (detected with monoclonal antibody mAb AT8) and Ser235 (mAb AT180), other sites, Ser422 and Ser396/S404 (mAb PHF1), were phosphorylated later in more advanced stages of the disease. ${ }^{76}$

\section{Anti-tau immunizations in mouse models}

NFTs are associated with two neurodegenerative diseases: $\mathrm{AD}$ and frontotemporal dementia. In AD, NFTs form later in the disease following $A \beta 42$ accumulation, while in frontotemporal dementia no $A \beta 42$ accumulation is present.

Passive and active immunizations against tau have been analyzed in mice using several different mouse strains, as well as different phospho-tau peptides for active immunizations and anti-tau antibodies for passive immunotherapy. ${ }^{77-85}$ In the first report on results from immunizations with a 30 -amino acid-long phosphorylated tau peptide, an effect on the ratios of soluble and insoluble tau, reduction of tangle formation in the immunized mice, and functional benefits observed in behavior testing for these mice were shown. ${ }^{77}$ These findings were confirmed in later studies from the same laboratory. ${ }^{78,79}$ Since the mice carrying the P301L mutation develop severe motor impairments as tau pathology advances, it is not possible to analyze memory improvement in these mice, as behavior tests commonly used for memory and cognition, like the Morris water maze, radial arm maze, or the T-maze require extensive motor movement. In a new double-transgenic mouse model, htau/PS1, which shows spatial memory deficits earlier by 12 months of age, it was possible to show that active tau-peptide immunization can prevent cognitive impairments, which was tested by two different maze tests and object recognition. ${ }^{79}$

There has been only one report presenting an adverse effect of tau immunization in mice, in which the immunized mice developed a late form of experimentally induced autoimmune encephalitis similar to the autoimmune pathogenesis found in mice that had been immunized with myelin oligodendrocyte glycoprotein or myelin basic protein as myelin self-antigens. In this study, the mice had been immunized with full-length tau together with two strong inflammationinducing substrates - complete Freund's adjuvant (CFA) and pertussis toxin $(\mathrm{PT})^{80}$ - because the researchers were interested to see the effects of maximal immune-system activation after immunization with a self-antigen. In a second study, this group used a phosphorylated tau peptide with 
the same strong adjuvant combination, CFA and PT, and did not observe inflammatory or neurotoxic side effects, but found positive effects in increased microglial activity in brains from immunized mice and reduction of NFTs due to generation of anti-phospho-tau antibodies, which did not cross-react with full-length unhyperphosphorylated tau (the antigen used before), indicative of the importance of choosing the right target for the development of immunotherapeutic strategies. $^{81}$

Passive immunization with well-characterized anti-tau antibodies, mAbs PHF, which react with phosphorylated Ser396 and Ser404 of the hyperphoshorylated tau protein as an early pathologic conformational epitope on tau confirmed the results seen in active immunization studies. Mice treated with these antibodies showed marked reductions in tau pathology, which was measured with biochemical methods and histology, as well as a significant delay in loss of motor-function decline which was assessed in behavioral testings. ${ }^{82,83}$

Similar to $A \beta$ immunotherapy, there are several possibilities for antibodies to inhibit or slow the progression of disease. Antibodies might pass the blood-brain barrier and then enter neurons as well to modulate phosphorylation and/ or degrade tau directly. It has been shown that tau-targeted immunization reduces the degree of tau phosphorylation in both young and aged mice, ${ }^{77,84}$ thereby reducing soluble hyperphosphorylated tau species that are toxic. Tau-targeted immunization may clear tau species that are involved in intercellular spreading of tau pathology and may prevent the initiation of tau aggregation. ${ }^{11}$ Anti-tau antibodies may help to support clearing functions by astrocytes as these were found to be activated in mice with high NFT burden following active immunization. ${ }^{84}$ Similar to the proposed peripheral sink mechanism for $\mathrm{A} \beta$ immunotherapy, anti-tau antibodies may facilitate tau clearance from the brain into the periphery, as an increase in tau concentrations was observed in blood from tau-immunized mice. ${ }^{85}$ These common antibody-action mechanisms are shown in Figure 2.

\section{Links between these two pathologies}

From pathophysiological analysis in mice and AD patients, it has been shown that $A \beta$ accumulation precedes the formation of NFTs. It has also become clear that $A \beta$ influences tau pathology and tau can influence $A \beta$ pathology. Clearance of $\mathrm{A} \beta$ in humans or mice with immunotherapy had effects on tau pathology, and analysis of CSF levels for tau showed a reduction in patients that were positive-antibody responders in the stopped AN-1792 trial. ${ }^{36,86-89}$ In cell cultures of differentiated rat hippocampal neuronal cells, it was shown that $\mathrm{A} \beta 42$-oligomer administration directly led to tau phosphorylation at sites that discriminate among $\mathrm{AD}$ and non-AD subjects, which are Ser404, Thr231, Thr181, Ser202, and Thr205. This was found not only for synthetic $A \beta$ oligomers but also for soluble extracts from AD brain containing the A $\beta$ oligomers. ${ }^{90}$ A reduction of normal endogenous tau has been shown to ameliorate $\mathrm{A} \beta$-induced dysfunction and early

\section{AD immunotherapy}

Amyloid precursor protein

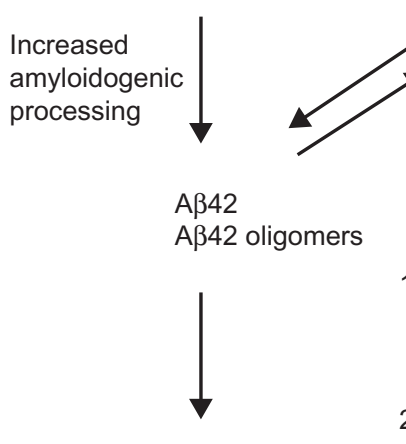

Senile plaques
Immunization
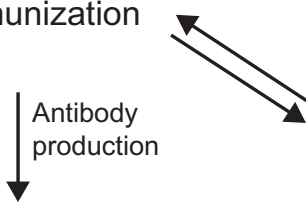

1. Antibody-antigen binding in blood creates concentration gradient (peripheral sink)

2. Antibodies inhibit aggregation

3. Antibodies increase clearance of misfolded proteins by microglia
Tau protein

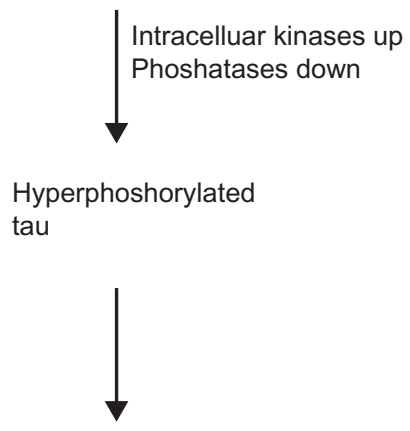

Neurofibrillary tangles

Figure 2 Common features of anti-amyloid beta $(A \beta)$ and anti-tau antibodies. Both pathophysiological hallmarks of Alzheimer's disease (AD) are caused by overproduction, aggregation, and misfolding of brain self-antigens. Active and passive immunotherapy and the respective anti-A $\beta$ and anti-tau antibodies share common features of antibody actions. 
mortality in transgenic mice, and tau reduction may thus be an option to treat AD symptoms. Epileptic seizures occur spontaneously in transgenic mice that overexpress APP at synapses, and it has been shown that the reduction of tau can decrease the incidence and severity of pharmacologically induced seizures without changes in $A \beta$ levels. Thus, tau somehow enables $A \beta$-induced neuronal dysfunction. ${ }^{91-93}$ In a recent study, it was shown how oligomeric $A \beta$ induces the phosphorylation of tau at specific sites, which drives neurons aberrantly into cell cycles without division (ectopic cell-cycle reentry), leading to cell death and neuron loss. The authors conclude that this might be one reason for the substantial neuronal cell loss in AD. ${ }^{94}$

While the ongoing and planned clinical trials are all concentrated on reduction of $A \beta$ brain levels, future studies might be needed to test whether targeting $A \beta$ and tau simultaneously can further improve the therapeutic efficacy of immunotherapy for AD.

\section{Acknowledgments}

This study was funded by grants from the NIH/NIA Alzheimer's Disease Center (P30AG12300-17), the Rudman Partnership, and the McCune Foundation.

\section{Disclosure}

DLW declares no conflicts of interest. RNR has received clinical trial research grants from Janssen Inc, Novartis, and Pfizer. He holds a US Patent for amyloid beta gene vaccines. He is also on the editorial board of the Journal of the American Medical Association (JAMA) and the editor of JAMA Neurology.

\section{References}

1. Alzheimer's Association. [homepage on the Internet]. Available at http:// www.alz.org/. Accessed July 24, 2013.

2. Selkoe DJ. Alzheimer's disease: genes, proteins, and therapy. Physiol Rev. 2001;81(2):741-766.

3. Wyss-Coray T. Inflammation in Alzheimer disease: driving force, bystander or beneficial response? Nat Med. 2006;12(9):1005-1015.

4. Lesné S, Koh MT, Kotilinek L, et al. A specific amyloid-beta protein assembly in the brain impairs memory. Nature. 2006;440(7082): 352-357.

5. Shankar GM, Li S, Mehta TH, et al. Amyloid-beta protein dimers isolated directly from Alzheimer's brains impair synaptic plasticity and memory. Nat Med. 2008;14(8):837-842

6. Lesné SE, Sherman MA, Grant M, et al. Brain amyloid- $\beta$ oligomers in ageing and Alzheimer's disease. Brain. 2013;136(Pt 5):1383-1398.

7. Billings LM, Oddo S, Green KN, McGaugh JL, LaFerla FM. Intraneuronal Abeta causes the onset of early Alzheimer's diseaserelated cognitive deficits in transgenic mice. Neuron. 2005;45(5): 675-688.

8. Oddo S, Caccamo A, Smith IF, Green KN, LaFerla FM. A dynamic relationship between intracellular and extracellular pools of Abeta. $\mathrm{Am}$ J Pathol. 2006;168(1):184-194.
9. LaFerla FM, Green KN, Oddo S. Intracellular amyloid-beta in Alzheimer's disease. Nat Rev Neurosci. 2007;8(7):499-509.

10. Clavaguera F, Bolmont T, Crowther RA, et al. Transmission and spreading of tauopathy in transgenic mouse brain. Nat Cell Biol. 2009;11(7): 909-913.

11. Frost B, Jacks RL, Diamond MI. Propagation of tau misfolding from the outside to the inside of a cell. J Biol Chem. 2009;284(19): $12845-12852$.

12. Citron M, Oltersdorf T, Haass C, et al. Mutation of the beta-amyloid precursor protein in familial Alzheimer's disease increases beta-protein production. Nature. 1992;360(6405):672-674.

13. Ashe KH, Zahs KR. Probing the biology of Alzheimer's disease in mice. Neuron. 2010;66(5):631-645.

14. Schenk D, Barbour R, Dunn W, et al. Immunization with amyloid-beta attenuates Alzheimer-disease-like pathology in the PDAPP mouse. Nature. 1999;400(6740):173-177.

15. Jankowsky JL, Slunt HH, Ratovitski T, Jenkins NA, Copeland NG, Borchelt DR. Co-expression of multiple transgenes in mouse CNS: a comparison of strategies. Biomol Eng. 2001;17(6):157-165.

16. Lewis J, McGowan E, Rockwood J, et al. Neurofibrillary tangles, amyotrophy and progressive motor disturbance in mice expressing mutant (P301L) tau protein. Nat Genet. 2000;25(4):402-405.

17. Oddo S, Caccamo A, Shepherd JD, et al. Triple-transgenic model of Alzheimer's disease with plaques and tangles: intracellular Abeta and synaptic dysfunction. Neuron. 2003;39(3):409-421.

18. Oddo S, Caccamo A, Kitazawa M, Tseng BP, LaFerla FM. Amyloid deposition precedes tangle formation in a triple transgenic model of Alzheimer's disease. Neurobiol Aging. 2003;24(8):1063-1070.

19. Filali M, Lalonde R, Theriault P, Julien C, Calon F, Planel E. Cognitive and non-cognitive behaviors in the triple transgenic mouse model of Alzheimer's disease expressing mutated APP, PS1, and Mapt (3xTgAD). Behav Brain Res. 2012;234(2):334-342

20. Oakley H, Cole SL, Logan S, et al. Intraneuronal beta-amyloid aggregates, neurodegeneration, and neuron loss in transgenic mice with five familial Alzheimer's disease mutations: potential factors in amyloid plaque formation. J Neurosci. 2006;26(40):10129-10140.

21. Cohen RM, Rezai-Zadeh K, Weitz TM, et al. A transgenic Alzheimer rat with plaques, tau pathology, behavioral impairment, oligomeric $\mathrm{A} \beta$, and frank neuronal loss. J Neurosci. 2013;33(15):6245-6256.

22. McMillan P, Korvatska E, Poorkaj P, et al. Tau isoform regulation is region- and cell-specific in mouse brain. J Comp Neurol. 2008;511(6): 788-803.

23. Hanes J, Zilka N, Bartkova M, Caletkova M, Dobrota D, Novak M. Rat tau proteome consists of six tau isoforms: implication for animal models of human tauopathies. J Neurochem. 2009;108(5): 1167-1176.

24. Priller C, Bauer T, Mitteregger G, Krebs B, Kretzschmar HA, Herms J. Synapse formation and function is modulated by the amyloid precursor protein. J Neurosci. 2006;26(27):7212-7221.

25. Westmark CJ. What's happening at synapses? The role of amyloid $\beta$-protein precursor and $\beta$-amyloid in neurological disorders. Mol Psychiatry. 2013;18(4):425-434.

26. Wilquet V, De Strooper B. Amyloid-beta precursor protein processing in neurodegeneration. Curr Opin Neurobiol. 2004;14(5): $582-588$.

27. Jonsson T, Atwal JK, Steinberg S, et al. A mutation in APP protects against Alzheimer's disease and age-related cognitive decline. Nature. 2012;488(7409):96-99.

28. Hardy J. New insights into the genetics of Alzheimer's disease. Ann Med. 1996;28(3):255-258.

29. Hardy J, Selkoe DJ. The amyloid hypothesis of Alzheimer's disease: progress and problems on the road to therapeutics. Science. 2002;297(5580):353-356.

30. Selkoe DJ. Amyloid beta-protein and the genetics of Alzheimer's disease. J Biol Chem. 1996;271(31):18295-18298.

31. Hardy J. Alzheimer's disease: the amyloid cascade hypothesis: an update and reappraisal. J Alzheimers Dis. 2006;9(Suppl 3):151-153. 
32. Games D, Adams D, Alessandrini R, et al. Alzheimer-type neuropathology in transgenic mice overexpressing V717F beta-amyloid precursor protein. Nature. 1995;373(6514):523-527.

33. Janus C, Pearson J, McLaurin J, et al. A beta peptide immunization reduces behavioural impairment and plaques in a model of Alzheimer's disease. Nature. 2000;408(6815):979-982.

34. Morgan D, Diamond DM, Gottschall PE, et al. A beta peptide vaccination prevents memory loss in an animal model of Alzheimer's disease. Nature. 2000;408(6815):982-985.

35. Orgogozo JM, Gilman S, Dartigues JF, et al. Subacute meningoencephalitis in a subset of patients with AD after Abeta42 immunization. Neurology. 2003;61(1):46-54.

36. Fox NC, Black RS, Gilman S, et al. Effects of Abeta immunization (AN1792) on MRI measures of cerebral volume in Alzheimer disease. Neurology. 2005;64(9):1563-1572.

37. Gilman S, Koller M, Black RS, et al. Clinical effects of Abeta immunization (AN1792) in patients with AD in an interrupted trial. Neurology. 2005;64(9):1553-1562.

38. Holmes C, Boche D, Wilkinson D, et al. Long-term effects of Abeta42 immunisation in Alzheimer's disease: follow-up of a randomised, placebo-controlled phase I trial. Lancet. 2008;372(9634):216-223.

39. Ryan JM, Grundman M. Anti-amyloid-beta immunotherapy in Alzheimer's disease: ACC-001 clinical trials are ongoing. J Alzheimers Dis. 2009; 17(2):243.

40. Schneeberger A, Mandler M, Otawa O, Zauner W, Mattner F, Schmidt W. Development of AFFITOPE vaccines for Alzheimer's disease (AD) - from concept to clinical testing. J Nutr Health Aging. 2009;13(3):264-267.

41. Winblad B, Andreasen N, Minthon L, et al. Safety, tolerability, and antibody response of active A $\beta$ immunotherapy with CAD106 in patients with Alzheimer's disease: randomised, double-blind, placebo-controlled, first-in-human study. Lancet Neurol. 2012;11(7): 597-604.

42. Davtyan H, Ghochikyan A, Petrushina I, et al. Immunogenicity, efficacy, safety, and mechanism of action of epitope vaccine ( $\mathrm{Lu}$ AF20513) for Alzheimer's disease: prelude to a clinical trial. J Neurosci. 2013;33(11):4923-4934.

43. Liu B, Frost JL, Sun J, et al. MER5101, a novel A $\beta 1-15$ :DT conjugate vaccine, generates a robust anti-A $\beta$ antibody response and attenuates $\mathrm{A} \beta$ pathology and cognitive deficits in APPswe/PS1 $\Delta \mathrm{E} 9$ transgenic mice. J Neurosci. 2013;33(16):7027-7037.

44. Pfeifer M, Boncristiano S, Bondolfi L, et al. Cerebral hemorrhage after passive anti-Abeta immunotherapy. Science. 2002; 298(5597):1379.

45. Salloway S, Sperling R, Gilman S, et al. A phase 2 multiple ascending dose trial of bapineuzumab in mild to moderate Alzheimer disease. Neurology. 2009;73(24):2061-2070.

46. Roher AE, Cribbs DH, Kim RC, et al. Bapineuzumab alters a $\beta$ composition: implications for the amyloid cascade hypothesis and anti-amyloid immunotherapy. PLoS One. 2013;8(3):e59735.

47. Adolfsson $\mathrm{O}$, Pihlgren $\mathrm{M}$, Toni N, et al. An effector-reduced anti- $\beta$ amyloid $(\mathrm{A} \beta)$ antibody with unique a $\beta$ binding properties promotes neuroprotection and glial engulfment of A $\beta$. J Neurosci. 2012;32(28): 9677-9689.

48. Bohrmann B, Baumann K, Benz J, et al. Gantenerumab: a novel human anti-A $\beta$ antibody demonstrates sustained cerebral amyloid- $\beta$ binding and elicits cell-mediated removal of human amyloid- $\beta$. J Alzheimers Dis. 2012;28(1):49-69.

49. Laino, C. News from The American Neurological Association Annual Meeeting: Anti-Amyloid-Beta Drug Modestly Slows Cognitive Decline in Mild to Moderate AD. Neurology today. 2012: 12 (21), 34-38.

50. Farlow M, Arnold SE, van Dyck CH, et al. Safety and biomarker effects of solanezumab in patients with Alzheimer's disease. Alzheimers Dement. 2012;8(4):261-271.

51. Garber K. Genentech's Alzheimer's antibody trial to study disease prevention. Nat Biotechnol. 2012;30(8):731-732.
52. Ostrowitzki S, Deptula D, Thurfjell L, et al. Mechanism of amyloid removal in patients with Alzheimer disease treated with gantenerumab. Arch Neurol. 2012;69(2):198-207.

53. Alzheimer Research Forum. Networking for a cure. [webpage on the Internet]. Available from http://www.alzforum.org/new/detail.asp?id=3485. Accessed July 31, 2013.

54. Blennow K, Zetterberg H, Rinne JO, et al. Effect of immunotherapy with bapineuzumab on cerebrospinal fluid biomarker levels in patients with mild to moderate Alzheimer disease. Arch Neurol. 2011;69(8): 1002-1010.

55. Relkin NR, Szabo P, Adamiak B, et al. 18-Month study of intravenous immunoglobulin for treatment of mild Alzheimer disease. Neurobiol Aging. 2009;30(11):1728-1736.

56. Relkin N, Bettger L, Tsakanikas D, Ravdin L. Three-year follow-up on the IVIG for Alzheimer's phase II study. Alzheimers Dement. 2012;8 (Suppl 4):3-381.

57. Shayan G, Adamiak B, Relkin NR, Lee KH. Longitudinal analysis of novel Alzheimer's disease proteomic cerebrospinal fluid biomarkers during intravenous immunoglobulin therapy. Electrophoresis. 2012;33(13):1975-1979.

58. Dodel R, Rominger A, Bartenstein P, et al. Intravenous immunoglobulin for treatment of mild-to-moderate Alzheimer's disease: a phase 2, randomised, double-blind, placebo-controlled, dose-finding trial. Lancet Neurol. 2013;12(3):233-243.

59. Rosenberg RN. Treat Alzheimer disease before it is symptomatic. Arch Neurol. 2011;68(10):1237-1238.

60. Bateman RJ, Xiong C, Benzinger TL, et al. Clinical and biomarker changes in dominantly inherited Alzheimer's disease. $N$ Engl J Med. 2012;367(9):795-804.

61. Miller G. Stopping Alzheimer's before it starts. Science. 2012: 337(6096):790-792.

62. Morris JC, Aisen PS, Bateman RJ, et al. Developing an international network for Alzheimer research: the Dominantly Inherited Alzheimer Network. Clin Investig (Lond). 2012;2(10):975-984.

63. Reiman EM, Langbaum JB, Fleisher AS, et al. Alzheimer's Prevention Initiative: a plan to accelerate the evaluation of presymptomatic treatments. J Alzheimers Dis. 2011;26 Suppl 3:321-329.

64. Carrillo MC, Brashear HR, Logovinsky V, et al. Can we prevent Alzheimer's disease? Secondary "prevention" trials in Alzheimer's disease. Alzheimers Dement. 2013;9(2):123-131.

65. Qu B, Rosenberg RN, Li L, Boyer PJ, Johnston SA. Gene vaccination to bias the immune response to amyloid-beta peptide as therapy for Alzheimer disease. Arch Neurol. 2004;61(12):1859-1864.

66. Qu B, Boyer PJ, Johnston SA, Hynan LS, Rosenberg RN. A 342 gene vaccination reduces brain amyloid plaque burden in transgenic mice. $J$ Neurol Sci. 2006;244(1-2):151-158.

67. Qu BX, Xiang Q, Li L, Johnston SA, Hynan LS, Rosenberg RN. $\mathrm{A} \beta 42$ gene vaccine prevents $\mathrm{A} \beta 42$ deposition in brain of double transgenic mice. J Neurol Sci. 2007;260(1-2):204-213.

68. Qu BX, Lambracht-Washington D, Fu M, Eagar TN, Stüve O, Rosenberg RN. Analysis of three plasmid systems for use in DNA A beta 42 immunization as therapy for Alzheimer's disease. Vaccine. 2010;28(32):5280-5287.

69. Kim HD, Jin JJ, Maxwell JA, Fukuchi K. Enhancing Th2 immune responses against amyloid protein by a DNA prime-adenovirus boost regimen for Alzheimer's disease. Immunol Lett. 2007;112(1): 30-38.

70. Movsesyan N, Ghochikyan A, Mkrtichyan M, et al. Reducing AD-like pathology in 3xTg-AD mouse model by DNA epitope vaccine - a novel immunotherapeutic strategy. PLoS One. 2008;3(5):e2124.

71. DaSilva KA, Brown ME, McLaurin J. Reduced oligomeric and vascular amyloid-beta following immunization of TgCRND8 mice with an Alzheimer's DNA vaccine. Vaccine. 2009;27(9): 1365-1376.

72. Davtyan H, Mkrtichyan M, Movsesyan N, et al. DNA prime-protein boost increased the titer, avidity and persistence of anti-Abeta antibodies in wild-type mice. Gene Ther. 2010;17(2):261-271. 
73. Lambracht-Washington D, Qu BX, Fu M, Eagar TN, Stüve O, Rosenberg RN. DNA beta-amyloid (1-42) trimer immunization for Alzheimer disease in a wild-type mouse model. JAMA. 2009;302(16): 1796-1802.

74. Lambracht-Washington D, Qu BX, Fu M, et al. DNA immunization against amyloid beta 42 has high potential as safe therapy for Alzheimer's disease as it diminishes antigen-specific Th1 and Th17 cell proliferation. Cell Mol Neurobiol. 2011;31(6):867-874.

75. Lee G, Leugers CJ. Tau and tauopathies. Prog Mol Biol Transl Sci. 2012;107:263-293.

76. Deters N, Ittner LM, Götz J. Divergent phosphorylation pattern of tau in P301L tau transgenic mice. Eur J Neurosci. 2008;28(1): 137-147.

77. Asuni AA, Boutajangout A, Quartermain D, Sigurdsson EM. Immunotherapy targeting pathological tau conformers in a tangle mouse model reduces brain pathology with associated functional improvements. J Neurosci. 2007;27(34):9115-9129.

78. Sigurdsson EM. Tau-focused immunotherapy for Alzheimer's disease and related tauopathies. Curr Alzheimer Res. 2009;6(5):446-450.

79. Boutajangout A, Quartermain D, Sigurdsson EM. Immunotherapy targeting pathological tau prevents cognitive decline in a new tangle mouse model. J Neurosci. 2010;30(49):16559-16566.

80. Rosenmann H, Grigoriadis N, Karussis D, et al. Tauopathy-like abnormalities and neurologic deficits in mice immunized with neuronal tau protein. Arch Neurol. 2006;63(10):1459-1467.

81. Boimel M, Grigoriadis N, Lourbopoulos A, Haber E, Abramsky O, Rosenmann H. Efficacy and safety of immunization with phosphorylated tau against neurofibrillary tangles in mice. Exp Neurol. 2010;224(2): 472-485.

82. Boutajangout A, Ingadottir J, Davies P, Sigurdsson EM. Passive immunization targeting pathological phospho-tau protein in a mouse model reduces functional decline and clears tau aggregates from the brain. J Neurochem. 2011;118(4):658-667.

83. Chai X, Wu S, Murray TK, et al. Passive immunization with anti-Tau antibodies in two transgenic models: reduction of Tau pathology and delay of disease progression. J Biol Chem. 2011;286(39):34457-34467.
84. Bi M, Ittner A, Ke YD, Götz J, Ittner LM. Tau-targeted immunization impedes progression of neurofibrillary histopathology in aged $\mathrm{P} 301 \mathrm{~L}$ tau transgenic mice. PLoS One. 2011;6(12):e26860.

85. Troquier L, Caillierez R, Burnouf S, et al. Targeting phospho-Ser422 by active Tau immunotherapy in the THYTau22 mouse model: a suitable therapeutic approach. Curr Alzheimer Res. 2012;9(4):397-405.

86. Oddo S, Billings L, Kesslak JP, Cribbs DH, LaFerla FM. A $\beta$ immunotherapy leads to clearance of early, but not late, hyperphosphorylated tau aggregates via the proteasome. Neuron. 2004;43(3):321-332.

87. Oddo S, Vasilevko V, Caccamo A, Kitazawa M, Cribbs DH, LaFerla FM. Reduction of soluble Abeta and tau, but not soluble Abeta alone, ameliorates cognitive decline in transgenic mice with plaques and tangles. J Biol Chem. 2006;281(51):39413-39423.

88. Serrano-Pozo A, William CM, Ferrer I, et al. Beneficial effect of human anti-amyloid- $\beta$ active immunization on neurite morphology and tau pathology. Brain. 2010;133(Pt 5):1312-1327.

89. Boche D, Donald J, Love S, et al. Reduction of aggregated Tau in neuronal processes but not in the cell bodies after $A \beta 42$ immunisation in Alzheimer's disease. Acta Neuropathol. 2010;120(1):13-20.

90. De Felice FG, Wu D, Lambert MP, et al. Alzheimer's disease-type neuronal tau hyperphosphorylation induced by A beta oligomers. Neurobiol Aging. 2008;29(9):1334-1347.

91. Roberson ED, Scearce-Levie K, Palop JJ, et al. Reducing endogenous tau ameliorates amyloid $\beta$-induced deficits in an Alzheimer's disease mouse model. Science. 2007;316(5825):750-754.

92. Ittner LM, Ke YD, Delerue F, et al. Dendritic function of tau mediates amyloid-beta toxicity in Alzheimer's disease mouse models. Cell. 2010;142(3):387-397.

93. Roberson ED, Halabisky B, Yoo JW, et al. Amyloid- $\beta /$ Fyn-induced synaptic, network, and cognitive impairments depend on tau levels in multiple mouse models of Alzheimer's disease. J Neurosci. 2011;31(2): 700-711.

94. Seward ME, Swanson E, Norambuena A, et al. Amyloid- $\beta$ signals through tau to drive ectopic neuronal cell cycle re-entry in Alzheimer's disease. J Cell Sci. 2013;126(Pt 5):1278-1286.
ImmunoTargets and Therapy

\section{Publish your work in this journal}

ImmunoTargets and Therapy is an international, peer-reviewed open access journal focusing on the immunological basis of diseases, potential targets for immune based therapy and treatment protocols employed to improve patient management. Basic immunology and physiology of the immune system in health, and disease will be also covered. In addition, the journal will focus on the impact of manage-
Dovepress

ment programs and new therapeutic agents and protocols on patient perspective such as quality of life, adherence and satisfaction. The manuscript management system is completely online and includes a very quick and fair peer-review system, which is all easy to use. Visit http://www.dovepress.com/testimonials.php to read real quotes from published authors. 